PRINT ISSN 1119-8362

Electronic ISSN 1119-8362
Full-text Available Online at

https://www.ajol.info/index.php/jasem

http://ww.bioline.org.br/ja
J. Appl. Sci. Environ. Manage.

Vol. 23 (9) 1621-1624 September 2019

\title{
Influence of Vermicast on Early Growth of Black Afara (Terminaliaivorensis A. Chev.) Seedlings
}

\author{
${ }^{* 1}$ ADEROUNMU, AF; ${ }^{2}$ OGUNWANDE, OA \\ ${ }^{1}$ Federal College of Forestry Ibadan, P.M.B 5087 Jericho Hill Ibadan Oyo State Nigeria \\ ${ }^{2}$ Forestry Research Institute of Nigeria, PMB 5054 Jericho Hill Ibadan Nigeria \\ *Corresponding Author Email: afaderounmu@gmail.com
}

\begin{abstract}
This study assessed the effect of vermicast on the early growth of Terminalia ivorensis A.Chev. (Black Afara) seedlings which belongs to the family Combretaceae. Seedlings were raised on Vermicast (100\%), Vermicast + Topsoil (1:1,) and topsoil media. There were three (3) treatments, replicated four (4) times and laid in Completely Randomized Design (CRD). The experiment was monitored for 12 weeks and the following variables were assessed, plant height $(\mathrm{cm})$, stem diameter $(\mathrm{mm})$, leaf production and the leaf area $\left(\mathrm{cm}^{2}\right)$. Data collected were subjected to descriptive statistics and Analysis of Variance (ANOVA). Results revealed that the seedling growth parameters measured were not significantly affected by the vermicast treatments at $5 \%$ probability level, except plant height. The best performance was observed in the seedlings raised with $T_{2}$ (Vermicast + Topsoil) in plant height, stem diameter, leaf production and leaf area with mean values of $28.55 \mathrm{~cm}, 0.55 \mathrm{~mm}, 18.25$ and $38.87 \mathrm{~cm}^{2}$ respectively while the least performance was recorded in $\mathrm{T}_{3}(100 \%$ top soil) in plant height, stem diameter, leaf production and leaf area with mean values of $22.06 \mathrm{~cm}, 0.49 \mathrm{~mm}, 15.25$ and $49.72 \mathrm{~cm}^{2}$ respectively. It is therefore recommended that $50 \%$ vermicast should be used to improve the growth media in order to enhance the early growth of Terminalia ivorensis seedlings at the nursery stage.
\end{abstract}

\section{DOI:https://dx.doi.org/10.4314/jasem.v23i9.2}

Copyright: Copyright $(\mathrm{C} 2019$ Aderounmu and Ogunwande. This is an open access article distributed under the Creative Commons Attribution License (CCL), which permits unrestricted use, distribution, and reproduction in any medium, provided the original work is properly cited.

Dates: Received: 12 June 2019; Revised: 13July 2019; 28 July 2019

Keywords: Vermicast, Terminalia ivorensis, Early Growth, Seedlings

Terminalia ivorensis, of the family Combretaceae is an important timber species in Nigeria. The tree of the species attains the heights of up to $50 \mathrm{~m}$ and girth of 5 $\mathrm{m}$, while young trees often attain only 1-1.5 m height after 5 years, compared to some other timber species, which are fast-growing (Osei-Begyina, 2007). The branches are whorled in young shoots and foliage (Keay, 1989). It is used for construction and other wood-based purposes and also serves as reforestation and afforestation species for devastated forest ecosystem (Jones and Averre, 2000). Soil nutrients and availability to crop are essential for the maximum production of food and trees in the development of any nation. However, soil nutrient decline is almost universal in Africa and this has led to the introduction and addition of both organic manure and inorganic fertilizers to enhance plant growth and productivity (Alabi et al., 2005). But there has been emerging concern for application of organic manures, as it may pose serious negative environmental impact. This led to the use of varieties of organic materials from both plants and animals for fertilizing the soil. As opined by Sinha et al., (2010), vermiculture technology is becoming prominent as an "environmentally sustainable", "economically viable" and "socially acceptable" technology all over the world. Vermicomposting is the term given to the process of conversion of biodegradable matter by earthworms into vermicast (Gajalakshmi and Abbasi, 2004). In this process, the unavailable nutrients contained in the organic matter are partly converted to more bioavailable forms. The use of earthworms was known for ages as "waste managers" for efficient "composting of food and farm wastes" and as "soil managers" for "fertility improvement" for "farm production (Gajalakshmi and Abbasi, 2002). Vermicast is an organic/natural fertilizer that is produced by using composting earthworm. This is produced by the feeding action of earthworms as they ingest organic matter, fragment and grind it into a finely divided peatlike material with high porosity aeration and water holding capacity. This process enhances microbial activities and accelerates the rate of decomposition. This leads to humification effect where unstable organic matter or decomposing plants and animal matters are oxidized and sterilized (Edward and Burrows, 1999).Vermicast enriches the soil and helps to ensure that plants receive all the nutrients needed to grow successfully. Such nutrients are Nitrate, 
exchangeable phosphorus, soluble potassium, calcium and magnesium (Edward and Burrows, 1999).

Due to climate change awareness which led to increase rate of tree planting, it has become expedient for nursery owners to produce healthy and vigorously growing seedlings essential for plantation establishment which may be achievable through the use of vermicast. Therefore, this study investigated the effect of vermicast fertilizer on the early growth of Terminalia ivorensis seedlings in the nursery.

\section{MATERIALS AND METHODS}

The experiment was carried out within the premises of Federal College of Forestry, Ibadan, Oyo State. It is located in Ibadan North West Local Government area of Oyo State. The area lies between latitude $7^{0} 26^{\prime} \mathrm{N}$ and Longitude $3^{0} 36^{\prime} \mathrm{E}$, the climatic condition of the area is tropically dominated by rainfall pattern ranging from $140 \mathrm{~mm}-1500 \mathrm{~mm}$, the average temperature is about $35.2^{\circ} \mathrm{C}$, the area experiences two distinct seasons which are dry and rainy seasons. The rainy season normally commences from April-October while the dry season commences from NovemberMarch. Seeds of Terminalia ivorensis were collected from the seed store of Sustainable Forest Management Department of Forestry Research Institute of Nigeria, Jericho Hill, Ibadan. The seeds were sown into wooden germination boxes $(60 \mathrm{~cm} \times 60 \mathrm{~cm})$, filled with washed and sterilized river sand while watering was done daily. After germination, resulted seedlings were pricked into polythene pot filled with topsoil which was analyzed in the laboratory for routine parameters using standard method. At two (2) weeks old, vigorous and uniformly growing healthy seedlings were selected and then transplanted into polythene pots filled with $2 \mathrm{~kg}$ of growing media, $\left(\mathrm{T}_{1}\right.$-Vermicast only, $\mathrm{T}_{2}$-mixture of topsoil and Vermicast $(1: 1, \mathrm{v} / \mathrm{v})$, and $\mathrm{T}_{3^{-}}$ topsoil only). The treatments were laid out in a Completely Randomized Design (CRD). Each of the three treatments was replicated four times. Parameters measured include: Seedling height $(\mathrm{cm})$, Leaf production, Stem diameter $(\mathrm{mm})$, Leaf Area $\left(\mathrm{cm}^{2}\right)$. The data collected were subjected to means, descriptive statistics and Analysis of Variance (ANOVA) to test for significance at $5 \%$ probability level.

\section{RESULTS AND DISCUSSION}

Physical and Chemical properties of the experimental soil: Some physical and chemical properties of the experimental soil are presented in Table 1. The soil was moderately acidic and loamy sand in texture. The organic carbon and available phosphorus are within the critical values of $15.0 \mathrm{~g}^{-1}$ and $10-16$ mgkg- $^{1}$ respectively (FMA and RD 2002). While total nitrogen content was lower than the critical value of $1.5 \mathrm{~kg}^{-1}$. Therefore, the soil was moderately suitable for the experiment.

Effects of Vermicast Treatments on Early Growth of T. ivorensis Seedlings: Seedling height: The analysis of variance revealed that vermicast treatments had significant effect on the seedling height of $T$. ivorensis (Table 2). Seedlings treated with mixture of topsoil and Vermicast at $1: 1, \mathrm{v} / \mathrm{v}\left(\mathrm{T}_{2}\right)$ recorded the highest mean height value of $28.55 \mathrm{~cm}$ while seedlings in Topsoil only $\left(\mathrm{T}_{3}\right)$ had the least mean value (Table 3 ). Generally, there was increase in the height of seedlings as the period of assessment increased (Fig. 1) but $\mathrm{T}_{2}$ showed remarkable increase throughout the period of assessment followed by $T_{1}$ while least values were recorded in $\mathrm{T}_{3}$. At week 2 after transplanting, $\mathrm{T}_{2}$ had $9.73 \mathrm{~cm}$ followed by $T_{1}(7.81 \mathrm{~cm})$ while least value was recorded in $\mathrm{T}_{3}$ with $6.83 \mathrm{~cm}$ and this order was followed throughout the period of assessment of the seedlings.

Stem diameter: According to Table 2, stem diameter of the seedlings was not significantly influenced by vermicast treatments though $\mathrm{T}_{2}$ recorded the highest mean diameter value of $10.96 \mathrm{~mm}$ while $\mathrm{T}_{3}$ recorded the least mean value with $9.64 \mathrm{~mm}$ (Table 3 ). Figure 2 shows that stem diameter increased throughout the period of assessment. At week 2 after transplanting, highest value was recorded for $T_{2}(0.4 \mathrm{~mm})$ followed by $\mathrm{T}_{1}(0.33 \mathrm{~mm})$ while least value was recorded in $\mathrm{T}_{3}$ $(0.32 \mathrm{~mm})$. This order was maintained throughout the period of assessment.

Number of leaves: Leaf production of the seedlings subjected to vermicast treatments were not significantly influenced (Table 2) as no significant difference was recorded in the mean number of leaves. But the highest mean number of leaves produced was recorded in $\mathrm{T}_{2}(0.48)$ followed by $\mathrm{T}_{1}(0.44)$ while the least was observed in $\mathrm{T}_{3}(0.42)$ (Table 3$)$. Throughout the period of assessment, there was increase in the number of leaves produced. At week 2 after transplanting, $\mathrm{T}_{2}$ had highest mean value of 4.8 while $\mathrm{T}_{3}$ had the least value of 4.3 . But at week $6, \mathrm{~T}_{1}$ had the highest mean value of 9.4 which later dropped at week 10. At week $10, \mathrm{~T}_{2}$ recorded the highest mean value (14.2) while least value was observed in $T_{3}$ with 11.85 (Fig. 3).

Leaf Area: The analysis of variance showed that leaf area of seedlings treated with vermicast was not significantly affected at $\mathrm{p} \leq 0.05$ (Table 2 ) but highest mean value was observed in $\mathrm{T}_{2}\left(38.87 \mathrm{~cm}^{2}\right)$ while least was recorded in $T_{3}$ with $30.16 \mathrm{~cm}^{2}$ (Table 3 ). 
Generally, leaf area increased throughout the period of study. At week 2 after transplanting, same value was recorded in $\mathrm{T} 1$ and $\mathrm{T} 2\left(12.9 \mathrm{~cm}^{2}\right)$ but at week 10 , highest value was recorded in $\mathrm{T}_{2}\left(46.94 \mathrm{~cm}^{2}\right)$ while $\mathrm{T}_{3}$ had the least value with $39.94 \mathrm{~cm}^{2}$ (Fig. 4).

Table 1: Results of physical and chemical properties of the top soil

\begin{tabular}{ll}
\multicolumn{2}{c}{ used } \\
\hline Soil parameters & Values \\
\hline Sand & 83.6 \\
Silt & 10.4 \\
Clay & 6.0 \\
Textural class & LOAMY SOIL \\
$\mathrm{pH}\left(\mathrm{CaCl}_{2}\right)$ & 5.8 \\
$\mathrm{CEC}\left(\mathrm{Cmol} \mathrm{kg}^{-1}\right)$ & 1.31 \\
Organic Carbon $\left(\mathrm{gkg}^{-1}\right)$ & 15.6 \\
Total Nitrogen $\left(\mathrm{gkg}^{-1}\right)$ & 1.16 \\
Available P $\left(\mathrm{mgkg}^{-1}\right)$ & 10 \\
\hline
\end{tabular}

Table 2: ANOVA for the mean effects of vermicast on early growth of Terminalia ivorensis seedlings

\begin{tabular}{|c|c|c|c|c|c|c|}
\hline Parameter & SV & $\mathrm{DF}$ & SS & MS & $\mathrm{F}$ & P-VALUE \\
\hline Height & $\begin{array}{l}\text { Treatments } \\
\text { Error } \\
\text { Total }\end{array}$ & $\begin{array}{l}2 \\
9 \\
11\end{array}$ & $\begin{array}{l}15.93562 \\
9.20275 \\
25.13837\end{array}$ & $\begin{array}{l}7.96781 \\
1.02253\end{array}$ & $7.7923^{*}$ & 0.0108 \\
\hline \multirow{2}{*}{$\begin{array}{l}\text { Stem } \\
\text { Diameter }\end{array}$} & Treatments & 2 & 0.00522 & 0.00261 & $0.4044^{=5}$ & 0.6789 \\
\hline & $\begin{array}{l}\text { Error } \\
\text { Total }\end{array}$ & $\begin{array}{l}9 \\
11\end{array}$ & $\begin{array}{l}0.05805 \\
0.06327\end{array}$ & 0.00645 & & \\
\hline \multirow{2}{*}{$\begin{array}{l}\text { Leaf } \\
\text { Production }\end{array}$} & Treatments & 2 & 1.88132 & 0.94066 & $0.3379^{s 5}$ & 0.7219 \\
\hline & $\begin{array}{l}\text { Error } \\
\text { Total }\end{array}$ & $\begin{array}{l}9 \\
11\end{array}$ & $\begin{array}{l}25.05558 \\
26.93689\end{array}$ & 2.78395 & & \\
\hline Leaf Area & $\begin{array}{l}\text { Treatments } \\
\text { Error } \\
\text { Total }\end{array}$ & $\begin{array}{l}2 \\
9 \\
11\end{array}$ & $\begin{array}{l}71.96802 \\
81.88488 \\
153.85289\end{array}$ & $\begin{array}{l}35.98401 \\
9.09832\end{array}$ & $3.9550^{t 5}$ & 0.05 \\
\hline
\end{tabular}

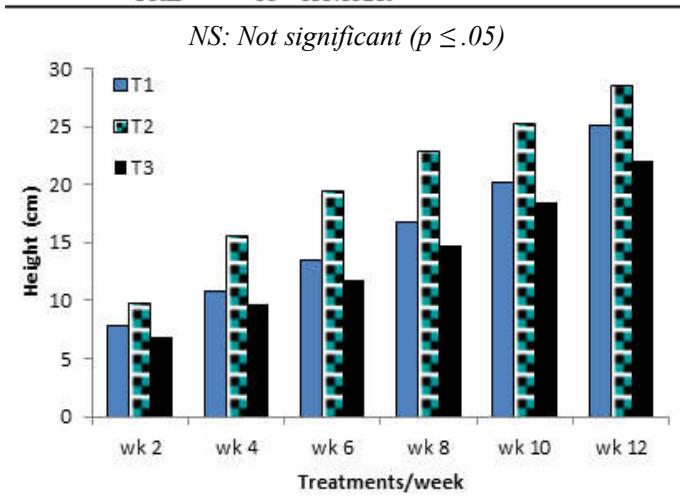

Fig 1: Mean effect of vermicast on the height $(\mathrm{cm})$ growth of Terminalia ivorensis seedlings

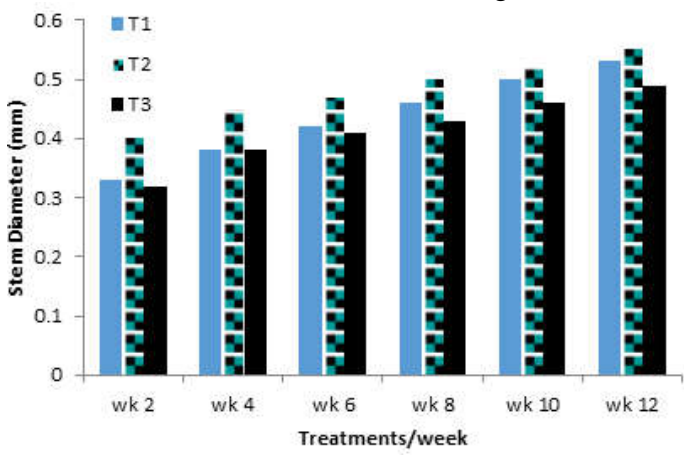

Fig 2: Mean effect of vermicast on the stem diameter ( $\mathrm{mm}$ ) of Terminaliaivorensis seedlings

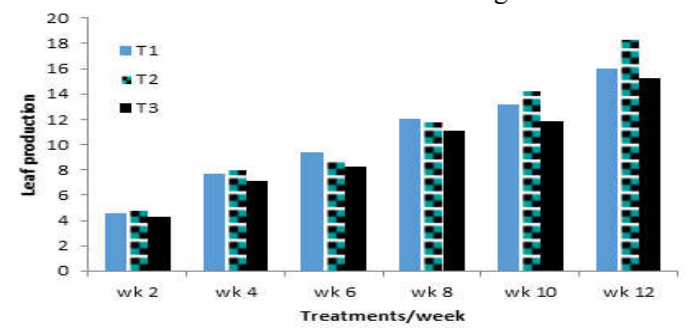

Fig 3: Mean effect of vermicast on the leaf production of Terminalia ivorensis seedlings

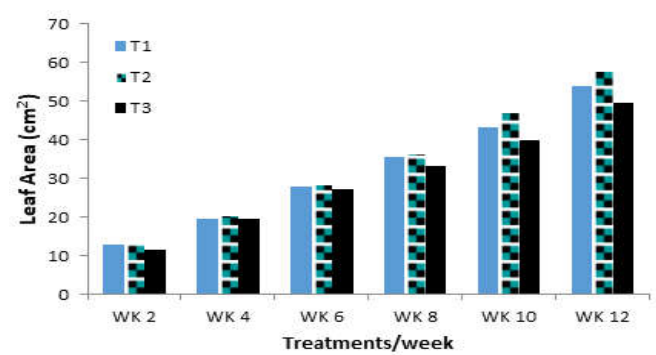

Fig 4: Mean effect of vermicast on the seedling leaf area $\left(\mathrm{cm}^{2}\right)$ of Terminalia ivorensis seedlings

Table 3: Follow-up test for the mean effect of vermicast on early growth Terminalia ivorensis seedlings

\begin{tabular}{lllll}
\hline TRT Seedlings & $\begin{array}{l}\text { Stem } \\
\text { Height(cm) } \\
(\mathrm{mm}\end{array}$ & $\begin{array}{c}\text { Diameter Leaf } \\
\text { Production }\left(\mathrm{cm}^{2}\right)\end{array}$ \\
\hline $\mathrm{T}_{1}$ & $25.07 \mathrm{ab}$ & 0.44 & 10.48 & 32.17 \\
$\mathrm{~T}_{2}$ & $28.55 \mathrm{a}$ & 0.48 & 10.96 & 38.87 \\
$\mathrm{~T}_{3}$ & $22.06 \mathrm{~b}$ & 0.42 & 9.64 & 30.16 \\
\hline
\end{tabular}

NOTE: Means with the same letter along the column are not significantly difference from one another

The vermicast is pellet-like excretions of earthworms known to contain elevated levelled nutrients, improves soil structure, and enhances fertility as well as habours beneficial microorganism than the surrounding soil or worm un-worked organic materials (Aranconet al., 2004; Kang and Ojo, 1996). In raising T. ivorensis seedlings, the mixture of equal quantities of vermicast and topsoil gave the best mean plant height, stem diameter, leaf production and leaf area growth of $28.55 \mathrm{~cm}, 0.48 \mathrm{~mm}, 10.96$ and $38.87 \mathrm{~cm}^{2}$ respectively, followed by the usage of $100 \%$ vermicast with $25.07 \mathrm{~cm}, 0.44 \mathrm{~mm}, 10.48$ and $32.17 \mathrm{~cm}^{2}$ respectively while the least performance was recorded in seedlings raised on topsoil only with $22.06 \mathrm{~cm}, 0.42 \mathrm{~mm}, 9.64$ and $30.16 \mathrm{~cm}^{2}$ respectively. The result was identical with Kumar et al.,(2011) and Shadanpour et al., (2011) who found that application of vermicompost increased the plant height in Stevia and Marigold, respectively. In another study, addition of vermicompost significantly increased the growth and yield of tomato plants compared to plant without it (control) (Azarmiet al., 2008). Agarwal et al., (2003) also recorded increased in growth parameters of Triticum aesticum by addition of earthworm cast to the soil used. This remarkable growth observed in the 
study may be attributed to the availability of optimum conditions necessary for plants growth. Dianda et al., (2009) and Oviasogie et al., (2013) also strongly support the use of alternative fertilizers from organic sources. Fertilizing plants from organic sources add value to soil in terms of replenishment, increased healthy growth and yield, improvement of the organic Carbon, Nitrogen, Phosphorus and Potassium availability in the soil.

Conclusion: This study showed that seedlings of Terminalia ivorensis grown in $\mathrm{T}_{2}$ (Vermicast + Topsoil, 1:1) had the best performance in terms of height, stem diameter, leaf production and leaf area and this is a clear indication that vermicast contains the required nutrients needed for the plant growth. Therefore, it could be recommended that vermicast be adopted to improve the growth of $T$. ivorensis seedlings especially at the nursery stage.

\section{REFERENCES}

Agarwal, SB; Singh, A; Dwivedi, G (2003). Effect of vermicompost, farmyard manure and chemical fertilizers on growth and yield of wheat (Triticumaestivum) L. var HD 2643. Plan. Arch. 3:914

Alabi, DA; Akinsulire, OR; Sanyaolu, MA (2005). Qualitative determination of chemical and nutritional composition of Parkiabiglobosa (Jacq.) Benth. Afr. J. Biotechnol. 4 (8): 812-815.

Arancon, NQ; Edwards, CA; Atiyeh, RM; Metxger TD (2004). Effect of vermicomposts produced from food waste on the growth and yields of greenhouse peppers. Bio-res.n Technol. 93 (2):139-144

Azarmi, R; ParvizSharifiZiveh; Mohammad Reza Satari (2008). Effect of vermicompost on growth, yield and nutrition status of tomato (Lycoperscicumesculentum). Pak. J. Biol. Sci. 11:1797-1802

Dianda, M; Bayala, J; Diop, T; Ouedraogo, SJ (2009). Improving growth of Shea butter tree (Vitellariaparadoxa C.F.Gaertn.) seedlings using mineral N, P and Arbuscularmycorrhizal (AM) fungi. Biotechnol. Agron. Soc. Environ. 13(1):93-102.

Edwards, CA; Burrows, I (1999). The Potential of Earthworms Compost as plant growth media in Waste and Environmental Management. SPB Academic publishing, 2 (32)

Federal Ministry of Agriculture and Rural Development (FMA and RD) (2002). Fertilizer use management practices for crop in Nigeria.pp 1-40.
Gajalakshmi, S; Abbasi, SA (2002). Effect of the application of water hyacinth compost/vermicompost on the growth and flowering of Crossandraundulaefolia, and on several vegetables, Biores. Technol85: 197-199.

Gajalakshmi, S; Abbasi, SA (2004).Neem leaves as a source of fertilizer-fum-pesticide vermicompost, Biores. Technol. 92: 291-296.

Jones, RK;Averre, CW (2000). Damping-off in flower and vegetable seedlings: Plant Pathology extension. North Carolina State: University Ornamental Disease Note. No.14.

Kang, BT; Ojo, A(1996). Nutrient availability of earthworm cast collected from under selected woody agroforestry species .Plant. Soil. 178: 113-119

Keay, RWJ (1989). Trees of Nigeria. Oxford Science Publications. Clarendon press Oxford,

Kumar, ME; Charan, Gaval, Rajesh, A; Rathod, Pradeep; Chandregowda, M (2011). Effect of organic manures and bio-fertilizers on growth and yield of stevia (Stevia rebaudiana). J. Ecobiol. 29 (2): 81-88.

Osei-Begyina, A (2007). Effect of inorganic (NPK) fertilizer on the growth rate of one-year old Diospyrosmespiliformis. B.Sc. thesis, Department of Silviculture and Forest Management, Faculty of Renewable Natural Resources, Kwame Nkrumah University of Science and Technology, Kumasi, Ghana, 40.

Oviasogie, PO; Odewale, JO; Aisueni, NO; Eguagie, EI; Brown; G Okoh-Oboh (2013). Production, utilization and acceptability of organic fertilizers using palms and Shea tree as source of biomass. Afr. J. Agri. Res. 8(27): 3483-3494.

Shadanpour, F; A Mohammadi Torkashy; K Hashemi Majd (2011). Marigold: The possibility of using vermicompost as the growth medium. J. Ornamen. Hort. Plants 1(3): 153-160

Sinha, RK, Agarwal, S., Chauhaan, K, Chandran, V; Soni, K (2010). Vermiculture technology: Reviving the dreams of Sir Charles Darwin for scientific use of earthworms in sustainable development programs. Technol. Invest. 1(3) 155-172 